IRA-International Journal of Education \& Multidisciplinary Studies

ISSN 2455-2526; Vol.14, Issue 01 (January, 2019)

Pg. no. 1-4.

Institute of Research Advances

Institute of

http://research-advances.org/index.php/IJEMS

\title{
The Influence of Reading Purpose on Second Language: Incidental Vocabulary Acquisition
}

Huang Shuke ", Pan Cuiqiong

School of Foreign Studies, Yangtze University, Hubei, 434023 PRC China.

\# corresponding author.

Type of Work: Peer Reviewed

DOI: http://dx.doi.org/10.21013/jems.v14.n1.p1

\section{How to cite this paper:}

Shuke, H., Cuiqiong, P. (2019). The Influence of Reading Purpose on Second Language: Incidental Vocabulary Acquisition. IRA International Journal of Education and Multidisciplinary Studies (ISSN 2455-2526), 14(1), 1-4.doi: http://dx.doi.org/10.21013/jems.v14.n1.p1

(C) Institute of Research Advances.

This work is licensed under a Creative Commons Attribution-Non Commercial 4.0 International License subject to a proper citation to the publication source of the work.

Disclaimer: The scholarly papers as reviewed and published by the Institute of Research Advances (IRA) are the views and opinions of their respective authors and are not the views or opinions of the IRA. The IRA disclaims of any harm or loss caused due to the published content to any party.

Institute of Research Advances is an institutional publisher member of Publishers International Linking Association Inc. (PILA-CrossRef), USA. The institute is an institutional signatory to the Budapest Open Access Initiative, Hungary advocating the open access of scientific and scholarly knowledge. The Institute is a registered content provider under Open Access Initiative Protocol for Metadata Harvesting (OAI-PMH).

The journal is indexed \& included in WorldCat Discovery Service (USA), CrossRef Metadata Search (USA), WorldCat (USA), OCLC (USA), Open J-Gate (India), EZB (Germany) Scilit (Switzerland), Airiti (China), Bielefeld Academic Search Engine (BASE) of Bielefeld University, Germany, PKP Index of Simon Fraser University, Canada. 


\begin{abstract}
In recent years, the study of incidental vocabulary acquisition has received worldwide attention from scholars at home and abroad. Based on the relevant literature and some relevant empirical studies, this paper mainly explores the influence of reading purposes on the incidental acquisition of second language vocabulary in natural reading. It also put forward some constructive suggestions on how to use these factors to guide students' vocabulary learning.
\end{abstract}

Keywords: Reading purpose; incidental vocabulary acquisition; second language.

\title{
1. Introduction
}

The famous British linguist D.A. Wilkins made it clear: "Without grammar, people can't express a lot of things, and without words, people can't express anything” (Wilkins 1972: 48). Thus, vocabulary is an indispensable part of the language. In view of this, the vocabulary acquisition process of L2 learners has attracted more and more attention in the field of L2 teaching and research, and the Incidental Vocabulary Acquisition is especially valued by scholars.

In 1985, Nagy, Herman and Anderson proposed the concept of incidental vocabulary acquisition. Specifically, it refers to in reading and listening, learners mainly focus on understanding the meaning of words, rather than specialized in learning words, and vocabulary acquisition is only produced by the secondary; It refers to the incidental acquisition of vocabulary knowledge in the process of reading comprehension (Laufer \& Hulstijn 2001). The corresponding concept of incidental acquisition is intentional vocabulary acquisition.

It is generally accepted that reading contributes to incidental vocabulary learning. According to the research (Gai Shuhua 2003a) the research on reading promoting incidental vocabulary learning is most fruitful (Laufer\& Hulstijn,2001; Pulido,2003) and most people believe that reading a large number of words is an effective way to expand vocabulary. However, how to achieve the highest incidental vocabulary acquisition efficiency in natural reading mainly depends on the relevant factors that influence the efficiency of second language incidental vocabulary acquisition. Generally speaking, there are many factors involved in the study of incidental vocabulary acquisition by second language learners, including discourse, learners, vocabulary and context. Because discourse, vocabulary and contextual factors are relatively much discussed, this paper attempts to explore the influential factors of incidental second language vocabulary acquisition in natural reading from the perspective of learners. In the learner factors, this paper mainly discusses the influence of reading purposes on the incidental acquisition of second language vocabulary in natural reading. It also put forward some constructive suggestions and suggestions on how to use these factors reasonably to guide students' vocabulary learning.

\section{An Analysis of The Influence of Reading Purposes on Second Language Incidental Vocabulary Acquisition}

Reading purpose refers to the purpose that learners hope to achieve through reading. Usually, reading motivation, reading interest and reading task determine the reading purpose. Different reading purposes will affect the level and manner of vocabulary processing, and then have different effects on the production and results of incidental vocabulary acquisition (Gai Shuhua 2003b).

Firstly, Laufer and Hulstijn (2001) proposed the involvement load hypothesis. This hypothesis is related to 
learners' needs and motivations. The greater the need for motivation, the greater the amount of involvement, the more incidental vocabulary acquisition is, and the better the retention is. This theory explains incidental vocabulary acquisition from the perspective of psychological cognition. For example, some students will have higher motivations in question-answered types than in multiple choice questions. Therefore, they can acquire more new words.

Secondly, the familiarity and interestingness of topics discussed in reading also have a significant impact on incidental vocabulary acquisition. If the reading material can attract readers, the learners will spontaneously understand the content of the text in order to deal with the reading materials related to new words (Pulido,2004) in a deeper level. So the more interesting the reading materials are, the better the incidental vocabulary acquisition is. Pulido (2003) concludes that if the topic of the reading material is familiar to the learner, the learner will be able to acquire more vocabulary incidentally.

Finally, many researchers at home and abroad have studied the effects of different reading tasks on incidental vocabulary acquisition (Hulstijn \& Laufer 2001). Kong Fanxia and Wang Xin (2014) explored the effects of task patterns and types on incidental vocabulary acquisition. Qi Lizhen (2009) made an empirical study on the effects of reading tasks on incidental vocabulary acquisition. The results show that the effects of vocabulary acquisition are influenced by different reading tasks.

From the above study, we can see that the different reading motivations, reading interests and reading tasks have a significant impact on incidental vocabulary acquisition. The greater the involvement of motivation, interest and task is, the better the incidental vocabulary acquisition effect is.

\section{The Implications of Vocabulary Acquisition Acquired by Reading Purpose to Vocabulary Teaching}

First of all, in terms of reading motivation, the learner's reading motivation is related to the motivation of the "involvement load hypothesis". The greater the motivational demand and input are, the better the vocabulary incidental learning effect is. Therefore, high-input reading tasks should be designed to ensure the motivational needs of learners.

Secondly, in terms of reading interest, in the choice of reading materials, the content of the discourse should be as lively and interesting as possible, close to the life of the learner, and avoid selecting those professional and strong technical articles.

Finally, for reading tasks, teachers should design appropriate reading tasks to ensure that learners thoroughly and comprehensively deal with vocabulary. Regarding the design of reading tasks, teachers can set up some tasks such as paragraphs retelling, fill in the blanks with a given target word or make sentences so that learners can finely process the new words and guide students to understand, remember and use the new words.

\section{Conclusion}

This paper mainly discusses the influence of reading purposes on the incidental acquisition of second language vocabulary in natural reading. In order to promote the development of second language vocabulary teaching, it also put forward some constructive suggestions and suggestions on how to use these factors reasonably to guide students' vocabulary learning. According to the study of this paper, incidental vocabulary acquisition in reading is a very complex mental cognitive process, which is affected by many factors, and these 
factors restrict each other. Therefore, in order to promote second language incidental vocabulary acquisition better, it is necessary to probe into various factors in depth.

\section{Reference}

[1]. Gai Shuhua. Overview of the study of incidental vocabulary acquisition[J].Journal of PLA University of Foreign Languages,2003a,(2): 73-76.

[2]. Gai Shuhua, 2003b, An Empirical Study of Vocabulary Acquisition in English Majors, Foreign Language Teaching and Research, No. 4.

[3]. Kong Fanxia, Wang Wei. Research on the Influence of Task Patterns and Types on Incidental Vocabulary Acquisition[J]. Foreign Languages, 2014, Volume Missing (6):21-29.

[4]. Laufer, B.,\& Hulstijn, J. H. Incidental vocabulary acquisition in a second language: The construct of task-induced involvement[J]. Applied Linguistics,2001,22(1): 1-26.

[5]. Nagy, W. E. , P. A. Herman \& R. C. Anderson. Learning words from context $[\mathrm{J}]$. Reading Research Quarterly, 1985( 20): 233-253.

[6]. Pulido, D. Modeling the role of second language proficiency and topic familiarity in second language incidental vocabulary acquisition through reading [J]. Language Learning, 2003, 53(2): 233-284.

[7]. Pulido, D. 2004.“ The relationship between text comprehension and second language incidental vocabulary acquisition: A matter of topic familiarity?". Language Learning 54/3.

[8]. Qi Lizhen. An empirical study on the impact of reading tasks on incidental vocabulary acquisition [J]. Journal of Mudanjiang Teachers College (哲社版), 2009( 1): 68-70.

[9]. Wilkins D A.Linguistics in Language Teaching[M].London: Edward Arnold, 1972.48. 